\title{
Plasma-chloride Levels in Hyperparathyroidism and Other Hypercalcaemic States
}

\author{
M. R. WILlS,* M.B., CH.B. ; G. K. McGowAN,† B.A., B.M., в.CH.
}

Brit. med.F., 1964, 1, 1153-1156

We record an analysis of plasma-chloride levels in patients with a raised plasma-calcium level, showing that chloride levels are nearly always higher in patients with hyperparathyroidism than in those with hypercalcaemia due to other causes.

\section{Material and Methods}

We have reviewed 61 patients in all ; 30 of these attended the United Bristol Hospitals, and 31 were seen at University College Hospital, London, by Professor C. E. Dent, who very generously offered his cases for inclusion in our series.

Thirty-three patients were suffering from primary hyperparathyroidism, confirmed at operation. In the other 28 hypercalcaemia was due to the following causes:

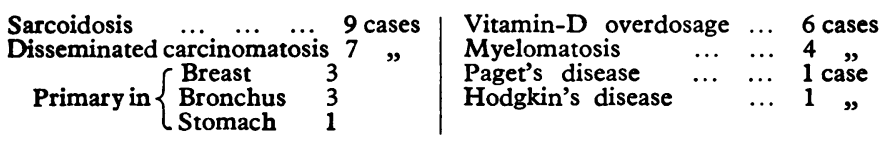

Of the patients receiving an overdose of vitamin $\mathrm{D}$ four were under treatment for hypoparathyroidism and one for resistant rickets. The sixth had tetany, which was never investigated sodium and potassium by internal standard flame-photometry, and urea by the autoanalyser standard micro-method.

In University College Hospital plasma calcium was estimated by the Eppendorf flame-photometer, phosphate according to Fiske and Subbarow (1925), and the remainder by autoanalyser standard methods.

\section{Results}

Fig. 1 shows plots of plasma calcium against plasma chloride for primary hyperparathyroidism and for hypercalcaemia due to other causes. There is little correlation between calcium and chloride levels within either group, but there is almost complete separation of the two groups on a basis of chloride level.

In the hyperparathyroid group there was only one patient with a plasma-chloride level less than $102 \mathrm{mEq} / \mathrm{l}$; this patient, with a level of $86 \mathrm{mEq} / 1$., had been vomiting profusely. The remainder had levels ranging from 102 to $118 \mathrm{mEq} / \mathrm{l}$. The average for the whole group was $106.5 \mathrm{mEq} / 1$.

Among the patients with hypercalcaemia due to other causes there was only one with a plasma-chloride level exceeding 102 $\mathrm{mEq} / \mathrm{l}$., the value being $103 \mathrm{mEq} / 1$. The remainder had levels ranging from 102 to $87 \mathrm{mEq} / \mathrm{l}$. The average for the whole group was 97.5 $\mathrm{mEq} / \mathrm{l}$. None of these patients had a significant history of vomiting or alkali administration.

Two of the hyperparathyroid patients and five of the others had plasma-chloride levels of $102 \mathrm{mEq} / 1$. and were therefore "borderline" cases, though of the five non-hyperparathyroid patients two had a second chloride estimation with a level of less than 102. If such multiple estimations are averaged, and if the dividing line is taken at $102.5 \mathrm{mEq} / 1$., then all the hyperparathyroid patients except three (of whom one was vomiting profusely) had higher levels, and all the hypercalcaemic patients except one had lower levels. If multiple estimations had been carried out on all borderline cases and an average value taken, the separation might have been even better.

It is impossible for such large differences in the concentration of a major anion such as chloride to occur unless there is either a

Frc. 1.-Plasma calcium plotted against plasma chloride. Triangles (left-band plot) represent patients with hyperparathyroidism. Circles (right-hand plot) indicate patients with hypercalcaemia due to other causes. Open symbols represent patients seen at the United Bristol
Hospitals, closed symbols those seen at University College Hospital, London. Symbols joined by line represent multiple estimations on one patient.

biochemically but was probably due to hyperventilation; her plasma calcium returned to normal after withdrawal of the vitamin.

In the United Bristol Hospitals plasma calcium was estimated by ethylenediaminetetra-acetate titration with a spectrophotometric end-point (Fales, 1953), phosphate according to Fiske and Subbarow (1925), chloride by potentiometric silver-nitrate titration (Sanderson, 1952), bicarbonate as $\mathrm{CO}_{2}$-combining power using a micromanometric apparatus (Natelson, 1951),

- Senior Registrar in Chemical Pathology, United Bristol Hospitals. + Consultant Chemical Pathologist, United Bristol Hospitals. corresponding change in the cations or a reciprocal change in some other anions, or a combination of both. The differences found in average plasma concentrations of sodium, potassium, calcium, bicarbonate, phosphate, and protein are given in Table I.

A rise in plasma-sodium level could well be the cause of the high chloride levels in hyperparathyroidism, in which a diabetes insipidus syndrome, causing water depletion, is known to occur (Cohen et al., 1957). Fig. 2a shows that there is in fact little or no correlation between plasma-sodium and plasma-chloride levels in either group. Nevertheless the average plasma-sodium level of the hyperparathyroid group is higher by $2.4 \mathrm{mEq} / 1$. 
TABLE I-Differences in Average Plasma Concentration of Ions Other than Chloride (Expressed in $\mathrm{mEq} / \mathrm{l}$.)

\begin{tabular}{|c|c|c|c|c|c|}
\hline & & & $\begin{array}{l}\text { Hyperpara- } \\
\text { thyroidism }\end{array}$ & $\begin{array}{c}\text { Other } \\
\text { Hypercalcaemias }\end{array}$ & Difference \\
\hline $\begin{array}{l}\text { Cations : } \\
\text { Sodium } \\
\text { Potassium } \\
\text { Calcium }\end{array}$ & $\begin{array}{l}\cdots \\
\cdots \\
\cdots\end{array}$ & $\begin{array}{l}\cdots \\
\cdots\end{array}$ & $\begin{array}{r}139 \cdot 9 \\
4 \cdot 25 \\
6.35\end{array}$ & $\begin{array}{r}137.5 \\
3.85 \\
5.95\end{array}$ & $\left.\left.\begin{array}{l}2 \cdot 4 \\
0 \cdot 4 \\
0 \cdot 4\end{array}\right\} 3 \cdot 2\right\}$ \\
\hline $\begin{array}{l}\text { Anions : } \\
\text { Bicarbonate } \\
\text { Phosphate } \\
\text { Proteins }\end{array}$ & $\begin{array}{l}\ldots \\
\ldots\end{array}$ & $\begin{array}{l}. \\
\cdots\end{array}$ & $\begin{array}{l}22 \cdot 8 \\
1.55 \\
16.8\end{array}$ & $\begin{array}{l}23 \cdot 7 \\
2 \cdot 35 \\
18 \cdot 0\end{array}$ & $\left.\begin{array}{l}0.9 \\
0.8 \\
1.2\end{array}\right\} 2.9$ \\
\hline
\end{tabular}

than that of the other group. The difference of potassium levels amounts to $0.4 \mathrm{mEq} / 1$., and that of calcium to $0.4 \mathrm{mEq} / 1$., making a total of $3.2 \mathrm{mEq} / 1$. for the three cations.

A reciprocal change of bicarbonate and chloride levels is often encountered-for example, in acid-base disturbances of respiratory or renal tubular origin. However, Fig. $2 b$, which shows a plot of plasma chloride against plasma bicarbonate, contain any record of plasma-chloride levels. Those which we have found with such levels are listed in Table II. We have not included cases of the milk-alkali syndrome where it is to be expected that the hypercalcaemia would be accompanied by alkalosis and a low plasma chloride; thus Wenger, Kirsner, and Palmer (1957), reporting a series of 35 patients with peptic ulcer on a regime of milk and calcium carbonate, found an average plasma-chloride level of $87.8 \mathrm{mEq} / 1$. with only one value above 102 , the plasma-calcium levels averaging 14.7 mg./100 ml., with a range of 11.3-18.3.

From Table II it will be seen that two out of the eight patients with hyperparathyroidism had plasma-chloride levels less than $102 \mathrm{mEq} / 1$., but both of these had been vomiting. Of the patients with hypercalcaemia due to other causes (excluding the milk-alkali syndrome) 6 out of 24 had levels of more than $102 \mathrm{mEq} / \mathrm{l}$.

These results from the literature do not show such a good separation of the two groups on a basis of chloride level as is seen in our series. This may be due partly to differences of technique for blood collection, plasma separation, and chloride estimation, and partly to the presence of interfering factors not mentioned in the published reports. In the two centres from which our cases were drawn, blood samples were usually taken by laboratory staff, with minimal stasis, into heparin and the plasma was separated as soon as possible. The fact that the results obtained at Bristol have been so closely confirmed by an entirely independent retrospective survey at University College Hospital gives us confidence that the high degree of separation which we have found between the plasma-chloride levels of the two groups is a genuine one.

Although we have found in the literature no mention of the value of plasma-chloride levels in the differential diagnosis of hypercalcaemia, Thomas, Connor, and Morgan (1958) and Howard (1962), have stressed that the plasma-bicarbonate level tends to be normal or low in hyperparathyroidism but is often high in hypercalcaemia due to other causes, but so far they have not published their full series of cases. Their claim is supported by an analysis of the published FIG. 2. -Above : Plasma chloride against plasma sodium. Below : Plasma chloride against
plasma bicarbonate. Symbols as in Fig. 1. Multiple values for one patient are averaged to provide a figure for calculating the mean for the whole group. reveals only a moderate inverse correlation in the hyperparathyroid group, and virtually none in the other group. Moreover, the difference in average plasma-bicarbonate level is only $0.9 \mathrm{mEq} / 1$. Of the other anions, phosphate shows an average difference of $0.8 \mathrm{mEq} / 1$, and proteins an average difference of $1.2 \mathrm{mEq} / 1$. (largely due to the four myelomatosis patients in the non-hyperparathyroid group), making a difference of $2.9 \mathrm{mEq} / 1$. for these three anions.

Differences in cations and anions together amount, therefore, to $6.1 \mathrm{mEq} / 1$. as compared with the $9 \mathrm{mEq} / 1$. difference in average chloride level. The small difference unaccounted for might be due to the differences in the level of magnesium and of other anions such as accumulate in uraemia and ketosis. In this connexion it may be significant that 13 of the 28 nonhyperparathyroid patients had plasma-urea levels of more than $50 \mathrm{mg}$. $/ 100 \mathrm{ml}$. as compared with 4 of the 33 hyperparathyroid patients.

\section{Discussion}

\section{Findings by Other Workers}

An examination of the literature soon reveals that it is uncommon for published cases of hyperparathyroidism or other forms of hypercalcaemia (except the milk-alkali syndrome) to cases which make up Table II ; all seven hyperparathyroid patients whose plasma bicarbonate was estimated have levels not exceeding $25.5 \mathrm{mEq} / 1$., whereas 18 out of 21 other hypercalcaemic patients have levels not less than $25.5 \mathrm{mEq} . / 1$. The differentiation between the two groups on a basis of bicarbonate is in fact better than that based on chloride levels. In our series, however, the differentiation between the two groups . on a basis of plasma bicarbonate is very poor (Fig. 2b) and not nearly so good as that based on chloride. Moreover, as shown in Table $I$, the difference in chloride levels can be largely accounted for by changes in ions other than bicarbonate.

We have at present no explanation of the discrepancy between the plasma-bicarbonate levels found in our patients and those reported by others. We had several reasons for expecting that there would be a reciprocal relationship between plasmachloride and plasma-bicarbonate levels. For instance, the parathyroid hormone is known to act on the kidney in such a way as might produce hyperchloraemic acidosis; several authors have shown that injections of parathyroid extract cause the urine to become more alkaline (Ellsworth and Howard, 1934 ; Ellsworth and Nicholson, 1935 ; Kleeman and Cooke, 1951 ; Nordin, 1960 ; Horwith, Rich, Thompson, and Rasmussen, 1961), while others have shown that some hyperparathyroid patients cannot acidify the urine normally after an ammonium-chloride load (Wrong and Davies, 1959 ; Fourman, 
McConkey, and Smith, 1960). So far as the other group is concerned, there is evidence that hypercalcaemia (provided that it is not due to hyperparathyroidism) may produce a hypo-

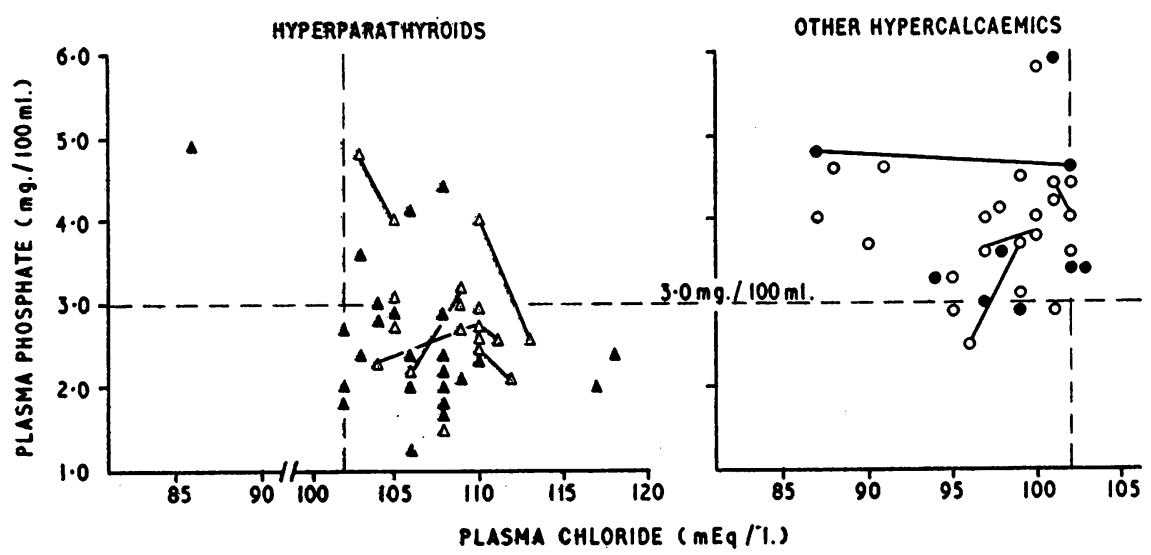

FIG. 3.-Plasma chloride against plasma inorganic phosphate. Symbols as in Fig. 1.

level in other forms of hypercalcaemia may also be low in some cases. Fig. 3 shows a plot of plasma chloride against plasma phosphate for our two groups, and reveals a much greater overlap of phosphate than of chloride values. If average values are taken for multiple phosphate estimations on any one subject, the non-hyperparathyroid group contains no patient with plasma levels of less than $2.9 \mathrm{mg}$., and only three with levels of less than $3 \mathrm{mg} . / 100 \mathrm{ml}$. In the hyperparathyroid group, however, there were eight patients with levels of more than 2.9 $\mathrm{mg}$. and seven with levels of more than $3 \mathrm{mg} . / 100 \mathrm{ml}$; at each level four of these patients had plasma-urea levels of more than $50 \mathrm{mg} . / 100 \mathrm{ml}$. Hence in this series random plasma-phosphate levels are inferior to random plasma-chloride levels in the differential diagnosis of hyperparathyroidism unless patients with plasma-urea levels of móre than $50 \mathrm{mg} . / 100 \mathrm{ml}$. are excluded, and this would mean excluding

chloraemic alkalosis, for calcium infusions have been shown to make the urine more acid in animals (Wolf and Ball, 1949 ; Wallach and Carter, 1961) and in man (Walter, 1951; Hänze, 1959) without any acid shift in the plasma. We are carrying out further investigations into the acid-base status of patients with hypercalcaemia.

\section{Diagnostic Value}

In the detection of hyperparathyroidism the most important biochemical finding is a raised plasma-calcium level. In the differential diagnosis from other forms of hypercalcaemia the plasma-inorganic-phosphate level is generally thought to be valuable, even though it is known that the phosphate level in hyperparathyroidism may fluctuate between low and normal, and be high if renal insufficiency is present, while the phosphate
13 patients in the other group as well as the four hyperparathyroid patients.

\section{Summary}

Of 33 patients with proved primary hyperparathyroidism, all had plasma-chloride levels of not less than $102 \mathrm{mEq} / 1$., except one patient who had been vomiting profusely.

Of 28 patients with hypercalcaemia due to other causes, all had plasma-chloride levels of not more than $102 \mathrm{mEq} / 1$., except one patient who had a level of $103 \mathrm{mEq} / 1$.

The plasma-chloride level appears to be superior to the plasma-inorganic-phosphate level for differentiating hyperparathyroidism from other conditions associated with hypercalcaemia.

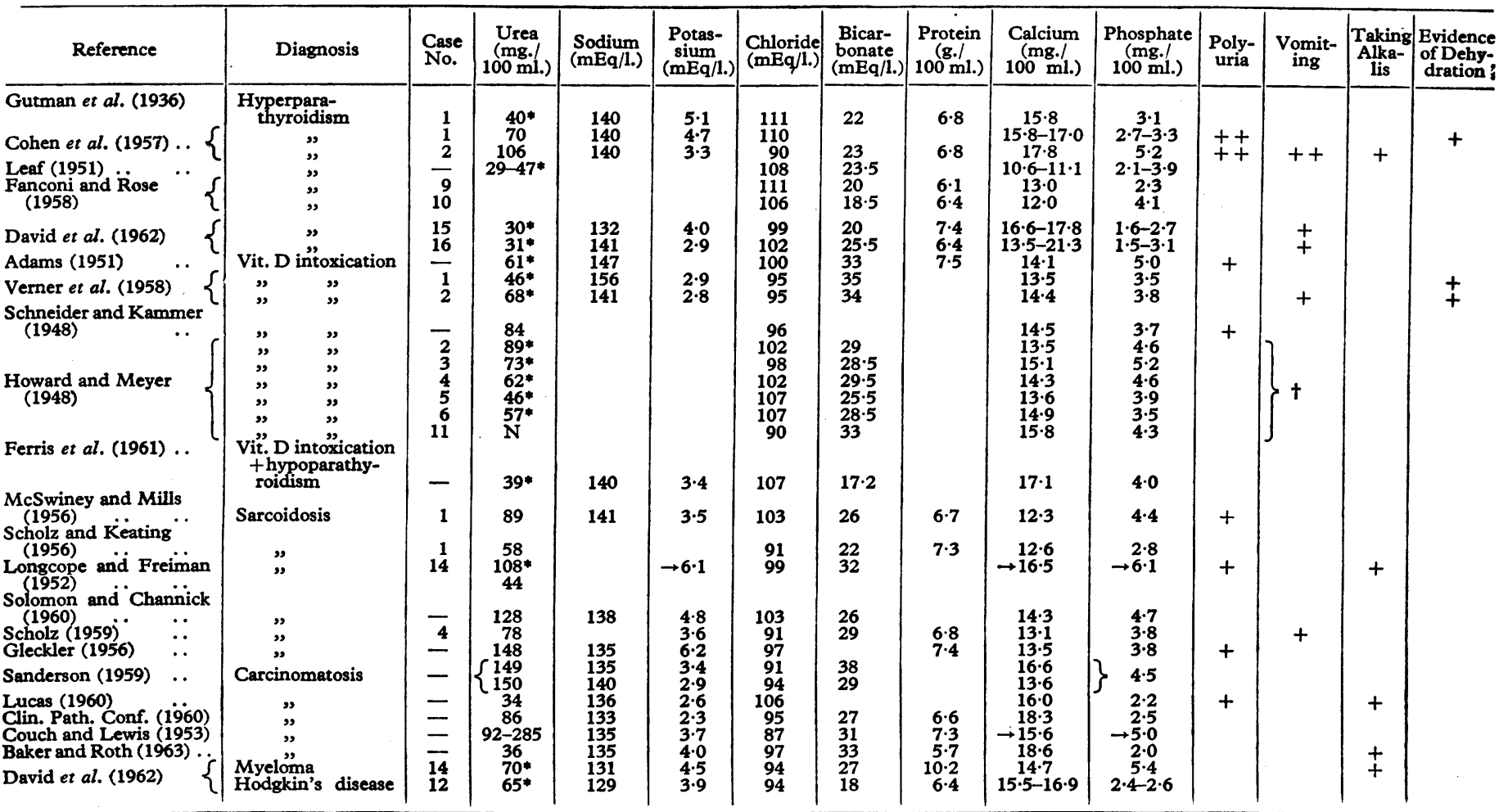


We are most grateful to Professor C. E. Dent for allowing us to include 31 of his cases from University College Hospital, and to Miss C. M. Harper, who extracted the relevant data from the case-notes of these patients. We also thank the physicians and surgeons of the United Bristol Hospitals for the opportunity to study their patients.

\section{REFERENCES}

Adams, F. D., (1951). New Engl. f. Med., 244, 590.

Baker, W. H., and Roth, S. I. (1963). Ibid., 269, 801.

Clin. Path Conf. (1960). Brit. med. F., 1, 1632.

Cohen, S. I., Fitzerald, M. G., Fourman, P., Griffiths, W. J., and De Wardener, H. E. (1957). Quart. F. Med., 26, 423.

Couch, R. S. C., and Lewis, A. A. G. (1953). Arch. Middx Hosp., 3, 84 David, N. J., Verner, J. V., and Engel, F. L. (1962). Amer. F. Med., 33, 88 .

Ellsworth, R., and Howard, J. E. (1934). Bull. Fohns Hopk., 55, 296

- and Nicholson, W. M. (1935). F. clin. Invest., 14, 823.

Fales, F. W. (1953). F. biol. Chem., 204, 577.

Fanconi, A. and Rose, G. A. (1958). Quart. f. Med., 27, 463.

Ferris, T., Kashgarian, M., Levitin, H., Brandt. I., and Epstein, F. H., (1961). New Engl. 于. Med., 265, 924.

Fiske, C. H., and Subbarow, Y. (1925). f. biol. Chem., 66, 375.

Fourman, P., McConkey, B., and Smith, J. W. G. (1960). Lancet, 1, 619.

Gleckler, W. J. (1956). Ann. intern. Med., 44, 174.

Gutman, A. B., Tyson, T. L., and Gutman, E. B. (1936). Ibid., 57, 379.
Hänze, S. (1959), Klin. Wschr., 37, 31.

Horwith, M., Rich, C., Thompson, D. D., and Rasmussen, H. (1961). In The Parathyroids, edited by $R$. O. Greep and R. V. Talmage, p. 415. Thomas, Springfield, IIl.

Howard, J. E. (1962). Trans. Coll. Phycns Philad., 30, 55.

Howard, Meyeı, R. J. (1948). f. clin. Endocr., 8, 895.

Kleeman, C. R., and Cooke, R. E. (1951). F. Lab. clin. Med., 38, 112

Leaf, A. (1951). New Engl. f. Med., 245, 504. Longcope, W. T., and Freiman, D. G. (1952). Medicine (Baltimore),

Lucas, P. F. (1960). Brit. med. f., 1, 1330.

McSwiney, R. R., and Mills, I. H. (1956). Lancet, 2, 862.

Natelson, S. (1951). Amer. f. clin. Path., 21, 1153.

Nordin, B. E. C. (1960). Clin. Sci., 19, 311.'

Sanderson, P. H. (1952). Biochem. F., 52, 502.

(1959). Brit. med. F., 2, 275.

Schneider, R. W., and Kammer, H. (1948). Cleveland Clin. Quart., 15, 82. Scholz, D. A. (1959). F. Amer. med. Ass., 169, 682.

- and Keating, F. R. (1956). Amer. 7. Med., 21, 75.

Solomon, R. B., and Channick, B. J. (1960). Ann. intern. Med., 53, 1232.

Thomas, W. C., Connor, T. B., and Morgan, H. G. (1958). F. Lab. clin. Med., 52, 11 .

Verner, J. V., Engel, F. L., and McPherson, H. T. (1958). Ann. intern. Med., 48, 765 .

Wallach, S., and Carter, A. C. (1961). Amer. f. Physiol., 200, 359.

Walter, O. (1951). Z. ges. inn. Med., 6, 664.

Wenger, J., Kirsner, J. B., and Palmer, W. L. (1957). Gastroenterology, 33, 745 .

Wolf, A. V., and Ball, S. M. (1949). Amer. F. Physiol., 158, 205.

Wrong, O., and Davies, H. E. F. (1959). Quart. F. Med., 28, 259.

\title{
Hodgkin's Disease and Hypogammaglobulinaemia : A Rare Association
}

\author{
B. I. HOFFBRAND,* B.M., B.CH., M.R.C.P.
}

Brit. med. F., 1964, 1, 1156-1158

Hypogammaglobulinaemia has been classified into three main groups (Lancet, 1962). This classification, though useful, is probably not entirely adequate as knowledge about the condition increases (Fudenberg and Franklin, 1963). The three groups are: (1) a primary congenital abnormality of sex-linked recessive inheritance, practically confined to boys ; (2) a primary, acquired disease occurring in adults of both sexes, with evidence that some cases at least involve a genetic factor (Fudenberg and Franklin, 1963 ; Hoffbrand, 1964) ; (3) a disease associated with, and presumed to be secondary to, various diseases involving the reticulo-endothelial system.

In the third group, chronic lymphatic leukaemia (Fairley and Scott, 1961), multiple myeloma (Eastham and Yeoman, 1960), and generalized lymphosarcoma (Ultmann, Fish, Osserman, and Gellhorn, 1959) are well recognized as being associated with a relatively high incidence of hypogammaglobulinaemia. Hodgkin's disease is also frequently stated to be responsible for such secondary, acquired hypogammaglobulinaemia (Lancet, 1958 ; 1962 ; Wolf, 1962). It was surprising, therefore, to be unable to find a single documented case of Hodgkin's disease, with repeated infections attributable to hypogammaglobulinaemia, or with a serum gamma-globulin level reduced to $200 \mathrm{mg}$. $/ 100 \mathrm{ml}$. or less, the level below which the Medical Research Council Working Party for Hypogammaglobulinaemia accepts a case of the primary disease for inclusion in its trial (Squire, 1960).

The rarity of hypogammaglobulinaemia in Hodgkin's disease may be more apparent than real, and may be due to differences in histological criteria of diagnosis, or to failure to recognize or publish cases. However, since the widespread introduction of electrophoresis, numerous workers have investigated the serum proteins in Hodgkin's disease (Petermann, Karnofsky,

* From University College Hospital, London. and Hogness, 1948 ; Rottino, Suchoff, and Stern, 1948 ; Arends, Coonrad, and Rundles, 1954 ; Cazal, Carli, and Fischer, 1956 ; Neely and Neill, 1956 ; Wall, 1958 ; Teitelbaum, Weiner, and Desforges, 1959 ; Krasnik and Baranowska, 1959 ; Goudemand and Foucaut, 1960 ; Onat and Cooper, 1960 ; Boggs and Fahey, 1960 ; Miller, 1962). These workers have examined the serum, often on more than one occasion, from no fewer than 417 cases of Hodgkin's disease, without finding one case with a serum gamma-globulin level approaching $200 \mathrm{mg} . / 100 \mathrm{ml}$. Wall (1958) specifically mentions the rarity of hypogammaglobulinaemia in Hodgkin's disease compared with the other lymphomas.

Two cases of Hodgkin's disease associated with serum gammaglobulin levels less than $200 \mathrm{mg}$. $/ 100 \mathrm{ml}$., as measured by a geldiffusion precipitin method (Gell, 1957), have been seen recently at University College Hospital. They are reported, together with the results of an as yet incomplete study of the immunoglobulins of the apparently healthy first-degree relatives of the two patients.

\section{Case 1}

\section{Case Histories}

A boy aged 12 was seen in October 1955 with a lump in the neck of one year's duration. He was otherwise well, with no notable past history, except chicken-pox at the age of 5. Biopsy of enlarged cervical lymph glands was performed, and the histological examination showed loss of architecture, a pleomorphic cellular infiltrate, and scanty Reed-Sternberg cells. A diagnosis of Hodgkin's disease was made. In view of his subsequent history, it is interesting to note that one gland sectioned at this time showed a relatively normal structure, with follicular hyperplasia and plasma cells.

Between October 1955 and March 1960 he received nine courses of radiotherapy to enlarged superficial lymph glands and his lumbar 